\title{
The Winter Food of the European Water-shrew
}

\author{
Krzysztof WOŁK ${ }^{1}$
}

\begin{abstract}
Wolk K., 1976: The winter food of the European water-shrew. Acta theriol., 21, 6: 117-129. [With 3 Tables \& 5 Figs.].

Examination was made of the food of the water-shrew Neomys fodiens (Pennant, 1771) which caught its prey in drainage ditches during two autumn-winter seasons. Remains of 940 partly consumed organisms were collected from the food tables, this number including insects, molluscs, amphibians and fish. Autumn and winter differ from each other in respect of the percentages formed by the food components. The food differentiation index markedly decreases during winter. The frequency of case-worm larvae does not change, but the percentages of remains of snails, frogs and adult insects significantly decrease. As winter proceeds the throughness with which water-shrews gnaw frogs increases. Penetration by the water-shrew of the areas in the vicinity of the food tables remains approximately uniform, despite differences in the composition and amount of food remains and water temperature.

[Mammals Res. Inst., Polish Acad. Sci., 17-230 Białowieża, Poland].
\end{abstract}

\section{INTRODUCTION}

One of the particularly interesting adaptations in mammals of the Insectivora order is the amphibious way of life of the water-shrew Neomys fodiens ( $\mathrm{P}$ ennant, 1771). Available data on the composition of the water-shrew's natural food (For mozov, 1948; T u pikova, 1949; S chreitmüller, 1953; Hawkins \& J ewell, 1962; B uchalczyk \& Pucek, 1963; Mezhzherin, 1964) are random and fragmentary, the greatest amount of material being contained in the penultimate publication referred to above. The present study forms a continuation of observations in this same field.

The whole of the analysis made of the material is based on the assumption that variations in the amounts of food remains found reflect variations in the water-shrew's food, although such remains do not represent the whole of this animal's diet.

\section{STUDY AREA, METHODS AND MATERIAL}

The study area consisted of meadows between the River Narewka and the edge of tree stands of the Białowieża National Park, generally speaking situated

1 Present address: Nature Protect. Lab., Forestry Res. Inst., 17-230 Białowież Poland. 
in the centre of the Białowieża Primeval Forest. The sectors of drainage ditches nearest the Białowieża National Park consisted of concrete pipes covered with soil. In the underground zone of this area two ditches joined and combined in one outlet at a distance of about $1 \mathrm{~km}$ from the river Narewka. The inlet of the ditches into the underground part were protected with iron gratings, which did not hinder the entry of animal organisms and also water-shrews. The water level in the underground pipes fluctuated, depending on rainfall or melting snow, usually from $1 / 4$ to $3 / 4$ of the interior of the pipe being filled with water. It was only exceptionally that the whole diameter of the pipe was completely filled with water. The underground part of the pipeline (Fig. 1 A) was divided into sections by wells built every $50 \mathrm{~m}$ (Fig. $1 \mathrm{~B}$ ). As two wells were situated slightly lower than the lower edge of the pipes, many water organisms were retained here in greater numbers than in the water flowing through the pipes. An exception was well no 4 , the bottom of which was on the same level as the pipes.

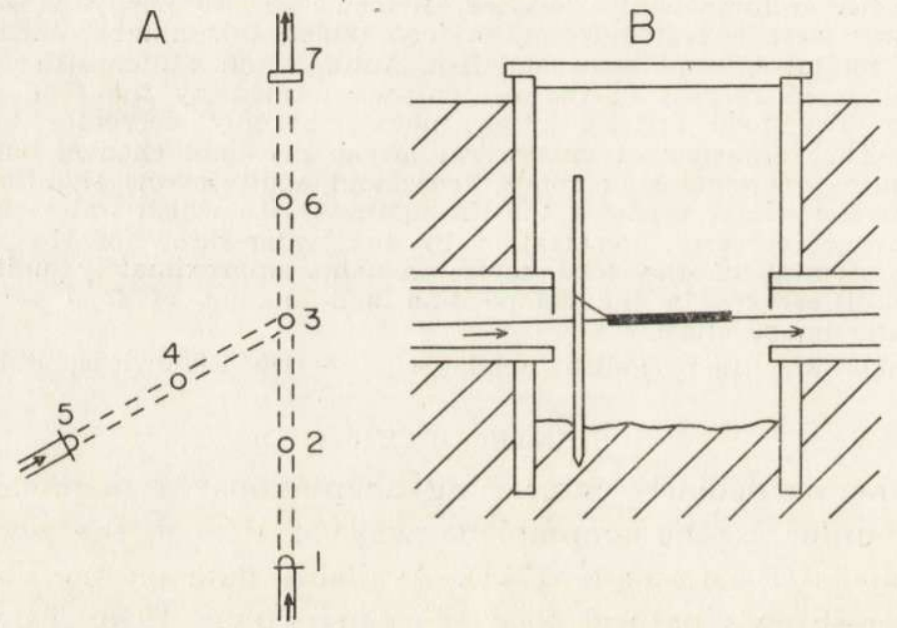

Fig. 1. Location of food table rafts.

A. Plan showing distribution of wells with rafts $(1-7)$ in the underground zone of drainage ditches (dotted line). B - Vertical cross-section of well with anchored raft (black). Arrows indicate direction of water flow.

B uchalczyk \& Pucek (1963) obtained material from the area at the end of pipe no. 7 (Fig. 1). In the autumn of 1966 it was found that the water-shrew still inhabited the burrow at the outlet of this pipe. All the wells were inspected and remains of food were found on the edges of the pipe outlets and on pieces of wood carried down by the water. The wood was removed from the wells, replaced by pieces of boards, on which the water shrew left food remains the same day. During the following two winters food remains left by the water shrew were collected from the artificial rafts.

These rafts were boards measuring $15 \mathrm{~cm} \times 50 \mathrm{~cm}$, the upper surface of which was edged with a wooden rim, and floats of foam plastic fastened underneath. They were placed on the surface of the water in the wells, and anchored by a wire loop fixed to a rod driven into the well bottom (Fig. 1 B). Wire loops 
made it possible to take the rafts out of the well by means of a hooked stick. Remains of food occasionally left on the edges of pipe outlets were collected by entering the wells. The concrete well covers were left tilted.

Each time inspection was made the food remains were, completely removed, portions from each working station being placed in separate bags. A total of 940 organisms killed by the water shrew were collected. A current record was kept of field observations, weather conditions and water level, and from time to time water temperature was measured in the various wells.

During the period from 7 Nov. 1966 to 4 May 1967 a total of 93 inspections were made and from 3 Nov. to 28 Febr. 1968 - 18. Frequency of inspection varied, with occasional periods of daily inspections. Calculations, with the exception of the total list of animals consumed, were based only on the results of inspections, when the rafts were effective in all the wells, i.e. 20 Nov. 1966 28 Febr. 1967.

The percentage values of the different groups of food were used to form a picture of changes in variations of the food. An index of food differentiation, calculated by means of the equation $a=10000 / \Sigma x^{2}$, in which $x$ indicates the percentage of the food group was used. This index was also used in studies of the food of fish (S z y p u la, 1971).

The number of water shrews living in the underground part of the drainage system can only be approximately estimated as 2-4 animals. In December 1966 attempts were made at catching the water shrews and marking them, by colouring the top of the head, but it proved necessary to discontinue this procedure as two of the individuals died. One colour-marked water shrew, swimming up stream, covered a distance of $100 \mathrm{~m}$ between wells no. 7 and no. 3 in 25 minutes. During the first few days of February an owl caught a water shrew on the surface of the water near well no. 7 (distinct traces on snow). There is no information to be found in available publications as to the possession of individual territory, or home range by water shrews in winter. In further consideration of these animals' food it has been assumed that several water-shrews, not exhibiting signs of territorialism, lived in the underground part of the drainage ditches.

\section{THE WATER-SHREW'S FOOD}

The remains of 940 animals organisms collected constitute a list of the water-shrew's food during the cold part of the year (autumn and winter), consisting of representatives of 24 species (Table 1). In both winters, despite the considerable difference in the numbers of the remains collected, they are similar in respect of the percentages formed by the food groups. Among the prey eaten in winter Insecta $\left(59.6 \%\right.$ and $\left.24.7^{\%} \%\right)$ dominate numerically, chiefly larvae of Trichoptera. The second in turn is Mollusca (22.1\% and 26.6\%), particularly snails (Gastropoda). The third position is occupied by Amphibia $(17.2 \%$ and $42.3 \%$ ), almost solely Rana temporaria overwintering in the bottom of drainage ditches. Then in turn comes Pisces $(0.7 \%$ and $11.3 \%)$, represented by Gasterosteus aculeatus, which only periodically appears in the parts of the ditches examined. One individual of Sorex araneus was found in the water-shrew's food, most certainly accidentally. Almost all the organisms caught by the 
water-shrew in winter are sluggish movers, only fish in cold water retaining relatively great activity.

The food obtained by the water-shrew in autumn differs from that in winter. In autumn remains of Mollusca form the greatest percentage $(72.2 \%)$. Amphibia forms $14.6 \%$ and Insecta $13.2 \%$. In winter food the most numerously represented species of Mollusca is Limnea stagnalis,

Table 1

List of prey eaten by European water-shrew during winter and autumn.

\begin{tabular}{|c|c|c|c|c|c|c|}
\hline \multirow[b]{2}{*}{ Species } & \multicolumn{4}{|c|}{ Winter } & \multicolumn{2}{|c|}{ Autumn } \\
\hline & $\begin{array}{l}\text { Nov. } 20, \\
\text { Febr. } 28, \\
n\end{array}$ & $\begin{array}{c}1966 \\
1967 \\
q \\
o\end{array}$ & $\begin{array}{l}\text { Nov } \\
\text { Febr } \\
\text { n }\end{array}$ & $\begin{array}{l}20,1967 \\
28,1968 \\
\%\end{array}$ & $\begin{array}{c}\text { Nov. } 1 \\
\text { Nov. } \\
\text { n }\end{array}$ & $\begin{array}{c}0-15,1966 \\
6-18,1967 \\
q\end{array}$ \\
\hline Insecta & 413 & 59.6 & 24 & $(24.7)$ & 20 & (13.2) \\
\hline Lymnephilus sp. indet. & 296 & 42.8 & 4 & & - & \\
\hline Notidobia sp. indet. & 48 & 6.9 & 3 & & 1 & \\
\hline Nepa sp. indet. & 42 & 6.1 & 5 & & 13 & \\
\hline Trichoptera indet. & 20 & 2.9 & 一 & & $\ldots$ & \\
\hline Molanna sp. indet. & 3 & 0.4 & 6 & & 5 & \\
\hline Anabolia sp. indet. & 3 & 0.4 & - & & $\cdots$ & \\
\hline Dytiscus sp. indet. & 1 & 0.1 & 6 & & 1 & \\
\hline Mollusca & 154 & 22.1 & 21 & $(21.6)$ & 109 & $(72.2)$ \\
\hline Lymnea stagnalis & 89 & 12.9 & 6 & & 9 & \\
\hline Galba corvus & 28 & 4.0 & 4 & & 2 & \\
\hline Bithynia tentaculata & 12 & 1.7 & - & & - & \\
\hline Radix peregra & 7 & 1.0 & 2 & & 88 & \\
\hline Planorbarius corneus & 6 & 0.9 & 4 & & 6 & \\
\hline Anodonta sp. indet. & 5 & 0.7 & - & & - & \\
\hline Viviparus contectus & 4 & 0.6 & 1 & & 2 & \\
\hline Galba truncatula & 1 & 0.1 & - & & $\therefore$ & \\
\hline Anisus sp. indet. & 1 & 0.1 & - & & - & \\
\hline Pisidium sp. indet. & 1 & 0.1 & 1 & & - & * \\
\hline Planorbis planorbis & - & - & 1 & & 1 & \\
\hline Bathyomphalus contortus & - & - & 1 & & - & \\
\hline Segmentina nitida & 一 & - & 1 & & 1 & \\
\hline Amphibia & 119 & 17.2 & 41 & $(42.3)$ & 22 & $(14.6)$ \\
\hline Rana temporaria & 119 & 17.2 & 40 & & 22 & \\
\hline Bufo bufo & - & - & 1 & & - & \\
\hline Pisces & & & & & & \\
\hline Gasterosteus aculeatus & 5 & 0.7 & 11 & (11.3) & - & \\
\hline Mammalia & & & & & & \\
\hline Sorex araneus & 1 & 0.1 & - & & $\cdots$ & \\
\hline Total & 692 & 99.7 & 97 & & 151 & \\
\hline
\end{tabular}

and in autumn Radix peregra. In winter the most numerously occurring representative of Insecta were Trichoptera (particularly Lymnephilus), and in autumn Nepa (representative of Heteroptera).

\section{ETHOLOGICAL OBSERVATIONS}

No planned ethological observations were made, but a record was kept of incidental observations. The food remains collected also form evidence 
of the water-shrew's behaviour. When feeding during the day the water-shrew dived and moved over the bottom with rapid movements difficult to follow. It always made for the food raft with the prey it had caught and consumed it on the raft. Changes in the appearance of the raft did not affect the animal's behaviour. It exhibited a marked tendency to get under cover, and as a rule consumed its prey under the roofs periodically set up on the rafts. Live-traps set up on the rafts, but not baited, also attracted it as roofs. The tendency to eat its food on food tables or rafts, i.e. in a place convenient for doing so, is very distinct when there were no rafts the water shrew consumed frogs on the protruding rim of the concrete pipe, pulling prey larger than itself up the vertical wall to a height of $30 \mathrm{~cm}$.

After eating the common shrew the water-shrew discarded the skin with limbs, tail, skeleton without the brain case and part of the ribs on the food table. The remains of sticklebacks left were the thoracic vertebrae, together with ribs and ventral fins, sometimes only the ventral fins in the form of spines. The majority of frog remains represented juvenile individuals of medium size. The water-shrew first bit them in the region of the thorax near the limbs. In the smallest individuals the head was consumed, without other parts of the body being injured, while the largest individuals had their eyes bitten out and their hands or feet bitten off. Snails with weaker shells were eaten by tearing out the body while simultaneously crushing the part of the shell. Snails with harder shells were dragged out from the interior without damaging the shell. Lamellibranchiata were eaten after cracking one of the two halves of the shell. Wings and legs were left over from the adult water insects eaten, and the casings of Trichoptera larvae, often only damaged to a slight degree.

The material collected gives an idea of the limits of the water-shrew's predatory capacity. Toads of varying size lived in the wells, but only one young individual of Bufo bufo, which had only a slightly bitten body under the fore-limb, was found in the material collected. It is not known what it is in the toad which repels the water-shrew - the thickness of its skin or its secretion (owls strip toads of their skin before eating them). Among snails it is only Viviparus sp. which has a sufficiently hard shell for the water-shrew to be unable to crush, and the operculum effectively protects this snail from being dragged out from the shell or from cracking the shell edge, but even so the water-shrew carried these snails from the water to the food table. It also carried juvenile Lamellibranchiata from the water, but was able to consume only those individuals with softer shells.

Water-shrews also carried inedible objects, but similar to their prey, 
from the water to the food table. Shells filled with mud were found twice, a lump of peat once and sodden flower receptacles three times - all objects similar in size and outline to snails. Sodden fragments of plants (mare's tail, a small twig, part of a stem) were found six times on the table, these objects being similar to the casings of Trichoptera larvae.

\section{DIFFERENCES BETWEEN FOOD TABLES IN RESPECT OF FREQUENCY OF FOOD REMAINS}

The food tables were placed in almost identical wells, with the exception of well no. 7, but they differed from one another as regards distance from the outlet of the pipes, kind of water flowing through them, and the order in which they were situated along the stream of water.
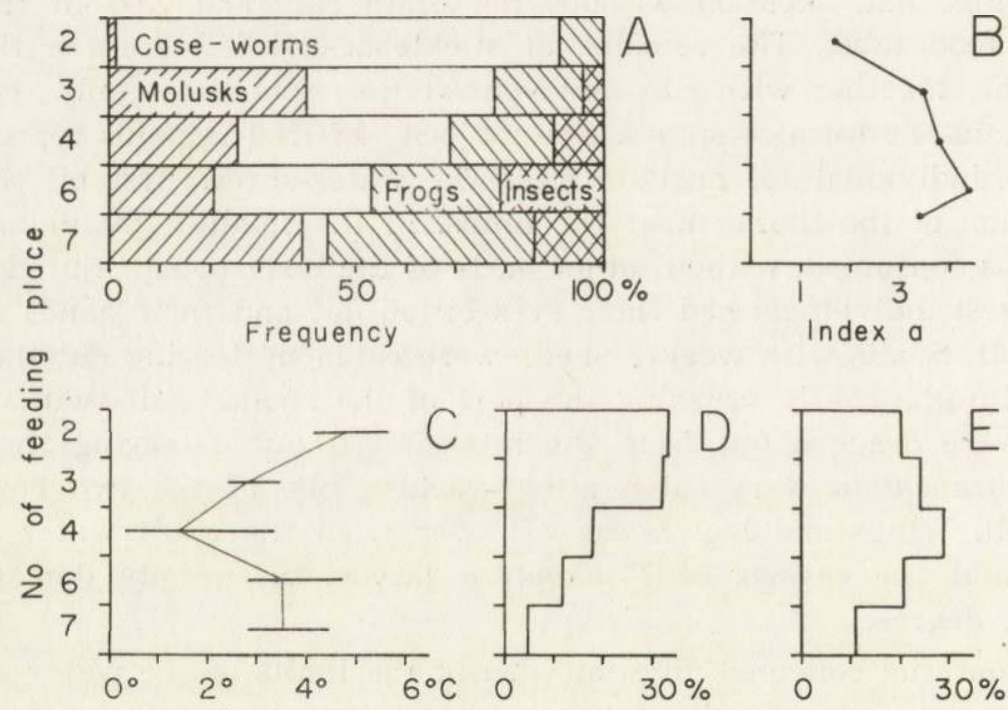

Fig. 2. Differences between food tables in wells nos. 2-4, 6 and 7 .

A - percentages formed by remains of individuals in the groups of food. B comparison of values of food differentiation index $(a)$. C - comparison of average, minimum and maximum water temperatures in the wells $(10$ measurements in December 1966). D - distribution in percentages of the number of individual prey found in different wells. E - distribution in percentages of frequency of finding remains of prey in the different wells.

Comparison of the percentages formed by groups of food remains collected from the various food tables revealed certain differences (Fig. 2 A). The tables differing most markedly are no. 2 and 7 , and those most similar are 3,4 , and 6 . In respect of the value of food differentiation index $a$ the tables are similar (Fig. 2 B), except for table no. 2, the lower value of the index of which is due to the numbers of Trichoptera larvae 
(Fig. 3). Wells differed in respect of water temperature (Fig. $2 \mathrm{C}$ ), which probably within the range of $0^{\circ}$ to $+6^{\circ} \mathrm{C}$ does not affect the activity of either the water-shrew or its pray.

The percentage of the number of remains of different individual victims left by the water-shrew on the various tables (Fig. $2 \mathrm{D}$ ) is highest for tables No. 2 and 3 (respectively 33 and 32), while the other tables differ considerably $(5-18 \%)$. Frequency of encountering food remains of any kind is, however, similar for all the tables except for the nontypical table no. 7 (Fig. $2 \mathrm{E}$ ), and this indicates that an approximately equal number of visits is paid to the tables by water-shrews.

The percentages for the distribution of food remains in the basic groups exhibit characteristic differences for the various food tables (Fig. 3). The remains of Trichoptera larvae were found mainly on table 2, while only negligible numbers of molluses and adult insects were found on it. The reason for this may be that the drainage ditch flowing into this well was very narrow, the stream of water rapid, the bottom sandy with
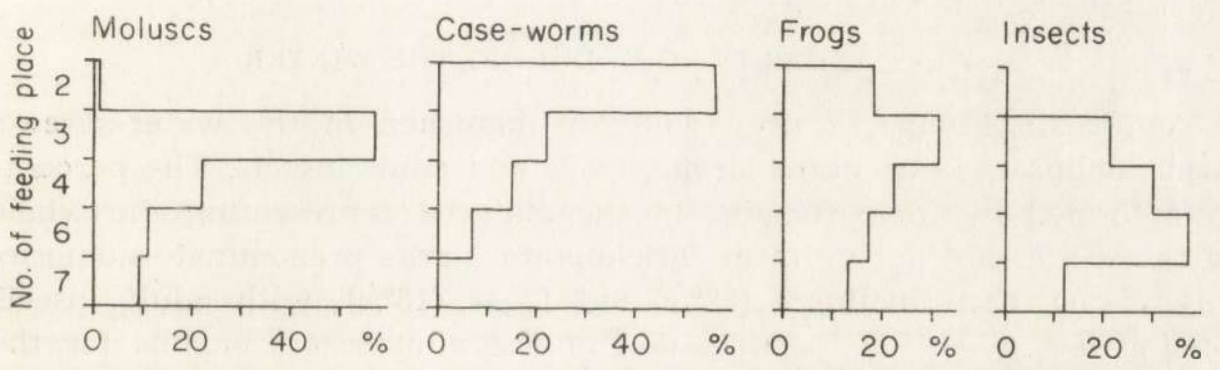

Fig. 3. Distributions in percentages of the number of remains for groups of prey in wells.

only a small amount of plants, and was therefore unsuitable for snails and adult insects, while the water transported Trichoptera larvae. The highest percentage for remains of frogs and molluscs and a considerable percentage of the other groups of food were found for table no. 3. Two ditches discharged water into this well (Fig. 1 A), carrying food from two directions. The largest amount of frog remains was found there. This can be explained by these amphibians' active penetration of all ditches in their search for a place in which to spend the winter. This explanation is further borne out by the relatively even percentage of frogs on tables in the other wells. The stream of water flowing into well no. 3 through well no. 4 runs from a wide drainage ditch with a slow current, muddy bottom and luxuriant vegetation. The percentages formed by the remains of all groups of food taken from table no. 4 are medium values, not higher (except for insects) than for table no. 3 , this being 
due to the extent to which the bottom of well no. 4 has silted up, and consequently fails to form a trap retaining organisms carried along by the water. The percentage distribution of mollusc remains provide convincing evidence they were carried by the water through well no. 4 and consumed to a record degree in well no. 3. Trichoptera larvae were intensively consumed in well no. 2 and formed only a small percentage in well no. 3.

The percentages formed by molluscs and case-worms were low in the case of table no. 6, medium for frogs and highest for adult insects. Molluscs and Trichoptera larvae passively borne along by the water were most certainly reduced in numbers in the vicinity of the preceding tables during their journey down, while actively-moving frogs and adult insects (predatory species) penetrated beneath the stream of water from the biologically richest ditch. The percentage formed by remains on table no. 7 is low, since this table is the last in the line of flow and the water-shrew (direct observations) also fed in the ditch outside the concrete pipe.

\section{CHANGES IN FOOD DURING THE WINTER}

Four main groups of prey were distinguished in the water-shrew's food: molluscs, Trichoptera larvae, frogs and adult insects. The percentages formed by their remains in the material representing the whole of the winter are not uniform: Trichoptera larvae predominate numerically $(54 \%)$, then molluses $(22 \%)$ and frogs $(18 \%)$, with adult insects coming last $(6 \%)$. The participation of the number of remains for the different groups of food changes in time (Fig. 4 B). Molluscs predominate at the end of November, Trichoptera larvae at the beginning and in the middle of December, frogs at the end of December, and Trichoptera larvae in January and February. The course taken by variations in the food differentiation index of the water-shrew (Fig. 4 C) permits of distinguishing three periods: (1) from the end of November to mid-December the value of the index is almost identical, (2) at the end of December and beginning of January (21.12-20.1) there are considerable fluctuations in the value of the index and (3) at the end of January and in February the value of the index is maintained on an even low level, pointing to the small degree of differentiation in the water-shrew's diet.

Analysis was made of variations in the amount of remains of prey from the different groups of food. Tendencies are illustrated by straight lines of regression running through the group of points defined by the amount of remains in a sample (Table 2). The numbers of adult insects and molluscs decrease during winter $(P<.001)$, while the numbers of Trichoptera larvae do not alter significantly during the winter. It is, how- 
ever, possible to distinguish two periods in the variations in numbers of frogs. During the first of these periods there are no significant variations, whereas in January and February a marked decrease can be observed in the number of frog remains $(.02<P<.01)$ (Table 2).

The fact that the numbers of Trichoptera larvae are maintained on a constant level during winter can be explained by the greater degree

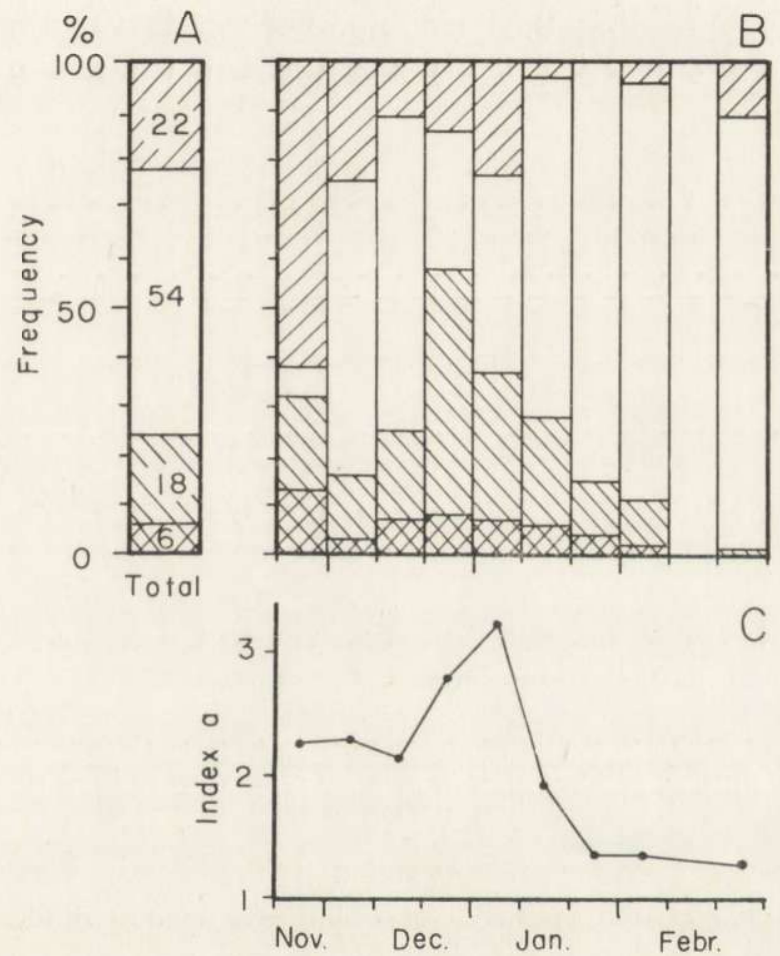

Fig. 4. Changes in numbers of food remains during winter. Symbols for groups of food as for Fig. $2 \mathrm{~A}$.

A - Percentages formed by remains of prey for whole winter. B - changes in percentages formed by remains of groups of prey for 10-day periods during winter. $\mathrm{C}$ - changes in value of food differentiation index $a$ during winter.

Table 2

Changes of water-shrew food remains during winter.

\begin{tabular}{|c|c|c|c|c|}
\hline Kind of food & Period & $\begin{array}{c}\text { No. } \\
\text { observations }\end{array}$ & Regression equation & Significance \\
\hline Insects ad. & Nov. $20-F e b r .28$ & 51 & $y=1.34-0.122 x$ & $P<.001$ \\
\hline Case-worms & Nov. 20 -Febr. 28 & 51 & $y=2.95+1.012 x$ & $.1>P>.05$ \\
\hline Molluses & Nov. 20 -Febr. 20 & 51 & $y=5.51-0.605 x$ & $P<.001$ \\
\hline Frogs & Nov. 20 -Dec. 31 & 31 & $y=1.30+0.675 x$ & $.1>P>.05$ \\
\hline Frogs & Jan. 1 -Febr. 28 & 20 & $y=4.87-0.877 x$ & $.02>P>.01$ \\
\hline
\end{tabular}


to which these organisms are susceptible to transport by water. The rate of flow of water through the ditches was not unfortunately measured, only those dates when the current was markedly more rapid than being recorded. Round about these dates the amount of remains of these larvae increased on the food tables. Five peaks in numbers were chosen from the study period, these peaks being revealed during the course of series of daily observations. Numbers were arranged together so that the first day is the day preceding the peak numbers of larvae remains (Fig. 5). The straight line of regression passing through the group of points de-

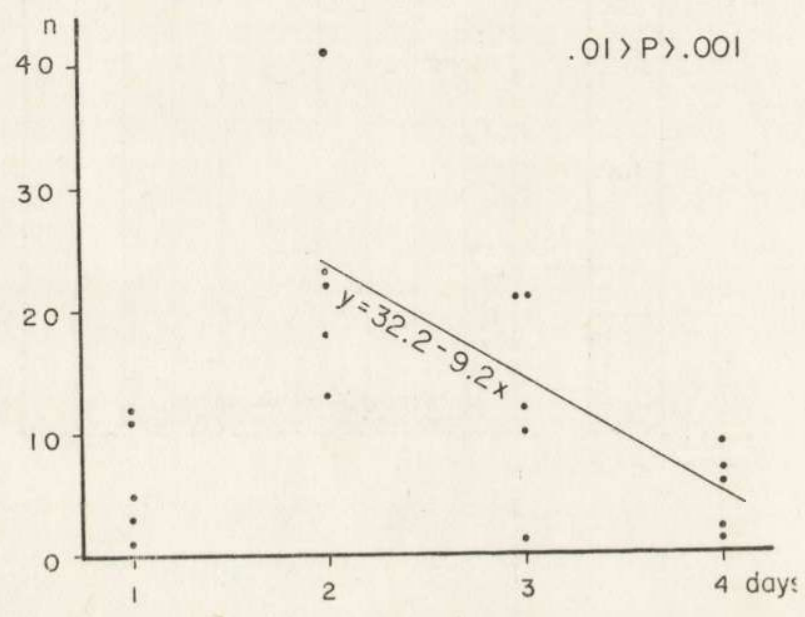

Fig. 5. Reduction in the number of remains of case-worms in successive days after their peak numbers.

Table 3

Changes of frog bodies gnawing rate during winter.

\begin{tabular}{lcccccc}
\hline Elements of frog bodies & Nov. 10 & Nov. 21 & Dec. 16 & Dec. 24 & Jan. 1 & Febr. 28 \\
\hline Whole frogs & + & & & & & \\
Fore feet & + & + & & & \\
Hind feet and muscles & + & + & + & & \\
Mandibles & + & + & + & + & \\
Skin & + & + & + & + & + & \\
\hline
\end{tabular}

fining the numbers of remains (n) declines significantly on days 2, 3 and 4 , as did the percentage distribution of numbers of larvae remains on the tables (Fig. 3 and Fig. 1 A). This shows how effectively water-shrews catch these case-worms.

The number of food tables on which food remains of any kind were found during single inspections also alters over the course of winter. Comparison of averages calculated for the above three periods revealed non-significant differences between the first and second period, but the 
average for the end of winter (period 3$)$ is significantly lower $(P<.001)$.

Out of all the study material only frogs were suitable for tracing changes in the degree to which they were gnawed by the water-shrew. Several elements of frog bodies were chosen, which with the passage of time from autumn to the end of winter gradually failed to appear on the food tables. The data given in table 3 show that the water-shrew gnaws its prey increasingly thoroughly.

\section{DISCUSSION}

Although studies were made in a man-made artificial structure, the water-shrew found conditions there similar to natural ones and constantly lived there. In winter the streams and drainage ditches in the area were covered with ice and drift snow and the fall in water level created an open space similar to that in concrete pipes. It is possible that the water-shrews living in concrete pipes were more secure from predators and had better food conditions, due to food being retained in the wells.

A list was made of the prey eaten in autumn and winter on the basis of the remains of the water-shrew's food collected. This list (Table 1) is undoubtedly far from complete, since (1) the water-shrews probably also consumed food in the tunnels of their burrows, eating the organisms encountered there, (2) remains of prey without any hard parts (such as dragonfly and May-fly larvae, leeches) were not left on the food tables, or fell into the water. Despite differences in the number of inspections and remains collected, the two winters exibit similarity in respect of the percentages formed by the groups of food, while data from autumn differ. It may therefore be assumed that the variations observed reflect differences in the water-shrew's diet from autumn to the end of winter.

Organisms eaten by the water-shrew differ greatly in respect of size and calorific value, but no relation was found between the amount of food remains and the size of the prey eaten, or between the numbers of prey in different groups. The species composition of remains of prey in single inspections also failed to reveal any regularity, apart from a general tendency to variations with the passage of time. Although the wells differed markedly from each other in many respects (Fig. $2 \mathrm{~A}-\mathrm{D}$, Fig. 3), they were penetrated to a relatively equal degree by the watershrews. It is clear from the above that there is no evidence of food preferences during winter. The water-shrews caught any edible organisms encountered (and also objects similar to their prey). T u pikova (1949), however, found by means of laboratory experiments that water-shrews prefer water organisms to land ones, and of water organisms prefer frogs. Hawkins \& J ewell (1960) found in their laboratory experiments that caterpillars are preferred to meal-worms. 
Towards the end of winter the food differentiation index is maintained on an even low level, showing that food conditions have deteriorated. This is also shown by the predomination in the water-shrew's diet at this time of càse-worms, prey of small size, and reduction in the number of remains of all the other groups of food, and also an increase in the degree of which frogs are gnawed. Further evidence of this is provided by the reduction in the average amounts of remains of their prey left by water-shrew. It is therefore possible that the maximum value of the food differentiation index reflects the increase in intensity of feeding by the water-shrew. Data on the diet of water-shrews in autumn are not random and are similar to those obtained earlier by $\mathrm{Buchalczyk}$ \& P u c e k (1963). These authors collected material on November 1st and 13th 1962 and 10-18th October 1962. The percentages calculated from their data were as follows - for Mollusca - 79.7\%, Amphibia $20.0 \%$, Pisces - $0.2 \%$. It can thus be seen that Mollusca, particularly Radix, predominated in the water-shrew's diet in both cases.

The purpose of storing in autumn frogs which have only been slightly gnawed (B u chalczyk \& Pucek, 1963; Sk oczeń, 1971) cannot as yet be definitely explained. Stores of frogs killed by water-shrews were also found at the beginning of both the study winters (in November). As they are collected it was impossible to discover whether the anims ls make use of the stores at a later date, but this is possible, since water-shrews were several times observed to search for and eat fragments of prey lying on the food table. The cause of accumulation of food in autumn may be due to the fact that it is abundant at that time, and also to the predatory behaviour of the water-shrew, since it is well known that whenever predators are able to do so they kill more animals than they consume (K r u u k, 1972).

Acknowledgements: I am greatly indebted to Mr. G. B a j k o, laboratory assistant, for so quickly and carefully making the rafts used, to Dr. W. R i edel for identifying the remains of case-worm larvae, and to Dr. A. R i e del for identifying snail remains. My thanks are also due to Professor $\mathrm{Z}$. Pucek for his critical reading of the first draft of this paper.

\section{REFERENCES}

1. Buchalczyk T. \& Pucek Z., 1963: Food storage of the European Water shrew, Neomys fodiens (P e n n n t, 1771). Acta theriol., 7, 19: 376-3i9.

2. Formozov A. N., 1948: Mielkie gryzuny i nasekomojadnye šarinskogo rajona kostromskoj oblasti v period 1930-1940 gg. Fauna i ékologija gryzunov, 3: 3-110 .

3. Hawkins A. E. \& Jewell P. A., 1962: Food consumption and energy requirements of captive British shrews and the mole. Proc. zool. Soc. Lond., 138, 1: 137-155.

4. Kruuk H., 1972: Surplus killing by carnivoren. J. Zool., 166: 233-244. 
5. Mezhzherin W. A., 1964: Javlenie Denelja i ego vozmožnoje ob'jasnenie. Acta theriol.. 8, 6: 95-114.

6. Schreitmülle r W., 1953: Wasserspitzmaus. Z. Säugetierk., 17: 149-151.

7. Skoczeń S., 1970: Gromadzenie zapasów pokarmowych przez niektóre ssaki owadożerne (Insectivora). Przegl. zool., 14, 2: 243-248.

8. Szypuła J., 1971: Współczynnik zróżnicowania pokarmu ryb. Wiad. ekol., 17, 3: $287-295$.

9. Tupikova N. V., 1949: Pitanie i harakter sutočnoj aktivnosti zemleroek srednej polosy SSSR. Zool. Ž., 28, 6: 561-572.

Accepted, May 15, 1975.

\section{Krzysztof WOEK}

\section{ZIMOWE POŻYWIENIE RZĘSORKA RZECZKA}

\section{Streszczenie}

Pożywienie rzęsorka rzeczka, Neomys fodiens (P e n n a n t, 1771) badano w rowach melioracyjnych łąki nadrzecznej w Puszczy Białowieskiej. W okresach 7 XI 1966-4 V 1967 i 3 XI 1967-28 II 1968 przeprowadzono 111 kontroli. Rzęsorki żerowały w części rowów melioracyjnych ujętych na pewnym odcinku w rury betonowe. Szczątki pożywienia tych zwierząt zbierano $z$ tratew, przez rzęsorki używanych jako stoliki pokarmowe, ustawionych w studniach (Ryc. 1). Listę zjadanych gatunków zestawiono na podstawie szczątków 940 organizmów stwierdzonych jesienią i zimą (Tab. 1). Rzęsorek wyciągał $\mathrm{z}$ wody na stoliki także przedmioty niejadalne a podobne do jego zdobyczy.

Szczegółowiej analizowano dane z zimy (20 XI 1966-28 II 1967). Mimo różnic usytuowania i temperatury wody studni (Ryc. 2 A-D), mimo różnic procentowego udziału szczątków pożywienia stoliki odwiedzane były równomiernie (Ryc. 2 E). Różnice między stolikami pod względem udziału grup pożywienia (Ryc. 3) daje się wytłumaczyć różnicami wpływających rowów melioracyjnych oraz właściwościami ekologicznymi zjadanych organizmów. W zebranym materiale dominują szczątki larw chruścików $(54 \%)$, następnymi są mięczaki $(22 \%)$ i żaby trawne $(18 \%)$, ostatnie miejsce zajmują owady dorosłe (6\% wszystkich szczątków).

Udział liczby szczątków poszczególnych grup pożywienia zmienia się w kolejnych dekadach (Ryc. 4 B). Pod koniec zimy dominują larwy chruścików, wtedy także wartość wskaźnika zróżnicowania pokarmu ustala się na niskim poziomie (Ryc. 4C). Wykazano, że w miarę upływu zimy liczby szczątków grup pożywienia maleją istotnie za wyjątkiem larw chruścików (Tab. 2). Szczątki żab w miarę upływu zimy były coraz staranniej obgryzione (Tab. 3). Powyższe dane mogą świadczyć o pogarszaniu się warunków troficznych rzęsorka pod koniec zimy. 